THE stimulation of granulocyte macrophage-colony stimulating factor (GM-CSF) by interleukin-1 (IL-1) has been shown to be counteracted in different mesenchymal cell systems by cyclic adenosine monophosphate (cAMP) agonists. The aim of this study was the evaluation of different cAMP agonists on GM-CSF expression in human bone marrow stromal cells. Incubation of secondary haematopoietic progenitor cell deprived human stromal cell cultures with IL-1 or TNF- $\alpha$ induced GM-CSF protein expression in culture supernatants and GM-CSFmRNA in adherent stromal cells. The coincubation with 8-bromo-cAMP (8BrcAMP), a water soluble cAMP analogue, inhibited this GM-CSF stimulation at the protein and the mRNA level. This effect was dose dependent with a maximal inhibition of about $65 \%$ occurring at a $8 B$ rcAMP concentration of $0.75 \mathrm{~m} \mathrm{M}$. In addition to $8 \mathrm{BrcAMP}$, other cAMP agonis ts such as dibutyryl-cAMP, forskolin, pertussis toxin, or prostaglandin $E_{2}\left(P E_{2}\right)$ had the same inhibitory effect on GM-CSF stimulation by IL-1. Coincubation with the cyclooxygenase inhibitor indomethacin had no significant influence on GM-CSF expression in stromal cells. Our results provide evidence that the previously described inhibitory effect of cAMP agonist $\mathrm{PGE}_{2}$ on haematopoietic progenitor cells in vivo is, at least in part, mediated by modulating the expression of GMCSF in bone marrow stromal cells.

Key words: GMFSF, bone marrow stromal cells, c-AMP, IL-1

\section{cAMP analogues downregulate the expression of granulocyte macrophage colony-stimulating factor (GM-CSF) in human bone marrow stromal cells in vitro}

\author{
G. Bug, J. Aman, C. Huber, C. Peschel and \\ H. G. Derigs ${ }^{\text {CA }}$
}

III Department of Medicine, Johannes Gutenberg University, Langenbeckstr. 1, D-55131 Mainz, Germany

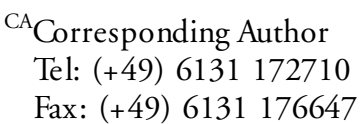

\section{Introduction}

The bone marrow stroma provides a microenvironment for proliferation and differentiation of haematopoietic stem and progenitor cells. Stromal cell cytokine production plays a pivotal role in controlling the development of sufficient mature blood cells under normal demands or after stimulation by inflammatory processes. ${ }^{1}$ GMCSF is a potent growth factor for a variety of haematopoietic progenitor cells. It is produced by Thymphocytes, macrophages and a variety of mesenchymal cells. ${ }^{2}$

Long-term bone marrow Dexter type cultures support the prolonged proliferation of haematopoietic progenitor cells, thereby providing an in vitro model for studies aimed at elucidating the mechanisms involved in haematopoietic regulation. The adherent layer of Dexter cultures is composed of mesenchymal bone marrow stromal cells. ${ }^{3}$ The regulation of grow th factor production in the adherent layer of Dexter type long-term bone marrow cultures closely resembles the in vivo situation. Multiple cytokines have been found in the supernatant of Dexter cultures, including GMCSF, G-CSF, M-CSF, interleukin-6, and leukaemia inhibitory factor (LIF). GM-CSF expression in mesenchymal cells is induced by inflammatory cytokines like IL-1 or TNF- $\alpha$ and is controlled at both the transcriptional and posttranscriptional levels. ${ }^{4-6}$

In this study, we used human stromal cell cultures to evaluate the effects of cAMP on the expression of GM-CSF, induced by inflammatory cytokines. We demonstrated that a variety of cAMP agonists inhibit the production of GM-CSF at the protein and mRNA level. These data indicate that the inhibitory effect of cAMP agonists like $\mathrm{PGE}_{2}$ on haematopoietic progenitor cells are, at least in part, mediated by modulating the expression of growth factors like GM-CSF in the bone marrow microenvironment.

\section{Materials and Methods}

\section{Material}

rh-IL-1 $\alpha$ was kindly provided by Hoffmann La Roche (Nutley, NJ), and rh-TNF $\alpha\left(6.6 \times 10^{6} \mathrm{U} / \mathrm{mg}\right)$ by Knoll AG (Ludwigshafen, Germany). Indomethacin, pertussis toxin, dibutyryl-cAMP, $8 \mathrm{BrcAMP} \mathrm{PGE}_{2}$, and forskolin were purchased from Sigma Chemicals (Deisenhofen, Germany), and $\alpha-{ }^{32}$ Ptabelled nucleotides from Amersham Buchler (Braunschweig, Germany). 


\section{Stromal cell culture}

Adherent bone marrow stromal cell cultures were essentially obtained as previously described. ${ }^{7}$ Bone marrow mononuclear cells, separated by centrifugation over Ficoll-Hypaque, were incubated at a cell density of $1 \times 10^{6} / \mathrm{ml}$ in $25 \mathrm{~cm}^{2}$ tissue flasks at $33^{\circ} \mathrm{C}$ in culture medium consisting of RPMI 1640 supplemented with $10 \%$ fetal calf serum (FCS), $10 \%$ horse serum, $1.0 \mu$ Mhydrocortisone (Sigma Chemicals), and the additives as described. ${ }^{7}$ In weekly intervals, cultures were fed by replacing $75 \%$ of the culture medium. When cultures were covered more than $80 \%$ by adherent cells, the primary cultures were treated with trypsin-EDTA (Biochrom, Berlin, Germany). Detached stromal cells were pooled and expanded in new culture flasks at a surface ratio of $1: 5$ in $75 \mathrm{~cm}^{2}$ tissue flasks. The adherent cells were incubated under the same culture conditions until the cultures became confluent again. By this culture method, homogeneous stromal cell layers were obtained that were morphologically and functionally comparable in different culture flasks. These cultures were devoid of all haematopoietic cells, including macrophages. Hydrocortisone was removed from these cultures at least 3 days before use for RNA and protein analysis. GM-CSF was measured in the culture supernatants of stromal cells after incubation for $24 \mathrm{~h}$ with various factors, as indicated in the Results section. For RNA analysis, the factors, as indicated in the Results section, were added simultaneously to parallel culture flasks from the same donor. After $6 \mathrm{~h}$ the cells were lysed directly in the culture flask with guanidium-isothiocyanate lysis buffer and processed as described below. The content of a $75 \mathrm{~cm}^{2}$ tissue flask yielded $10-20 \mu \mathrm{g}$ total RNA.

\section{Northern blot analysis}

Total cytoplasmic RNA was prepared using the single step method of guadinium/phenol-chloroform extraction as described earlier. ${ }^{8}$ Ten to $15 \mu \mathrm{g}$ of RNA (depending on the least yield obtained in each experiment) were subjected to electrophoresis on a $1 \%$ agarose-formaldehyde gel and transferred onto nylon membrane (Hybond-N, Amersham Buchler). Blots were hybridized to $\alpha^{32}$ Ptabelled cDNA probes using random primer DNA labelling kit (Boehringer), washed and exposed to Cronex 4 autoradiography films (DuPont) at $-70^{\circ} \mathrm{C}$. Human GM-CSF cDNA, an 800-bp EcoRI fragment cloned into P91023(B)-vector, was obtained from American Type Culture Collection (Rockville, MD).

\section{Enzyme-linked immunoabsorbent assay (ELISA)}

Concentrations of GM-CSF were measured using Quantikine Human Cytokine Immunoassays (R\&DSystems, Minneapolis, $\mathrm{MN}$ ) according to manufacturer's instructions. Sensitivity of the test for human GM-SF was $7.8 \mathrm{pg} / \mathrm{ml}$.

\section{Results}

Stimulated GM-CSF expression in human bone marrow stromal cells is inhibited by $8 \mathrm{BrcAMP}$

Expression of GM-CSF in human bone marrow stromal cells was assessed at the protein level in culture supernatants by a sensitive EUSA and at the mRNA level by Northern blot analysis. In unstimulated cultures no or very low levels of GM-CSF mRNA were detected. After incubation with IL-1 $(100 \mathrm{U} / \mathrm{ml})$ or TNF- $\alpha(500 \mathrm{U} / \mathrm{ml})$ for $6 \mathrm{~h}$, significant GM-CSF-mRNA expression was induced. IL-1 was shown to have a stronger stimulatory effect than TNF- $\alpha$ (Figs 1 and 2B). These RNA-data were confirmed at the protein level. IL-1 and TNF- $\alpha$ incubation for 24-h induced GM-CSF secretion into stromal cell culture supernatants with

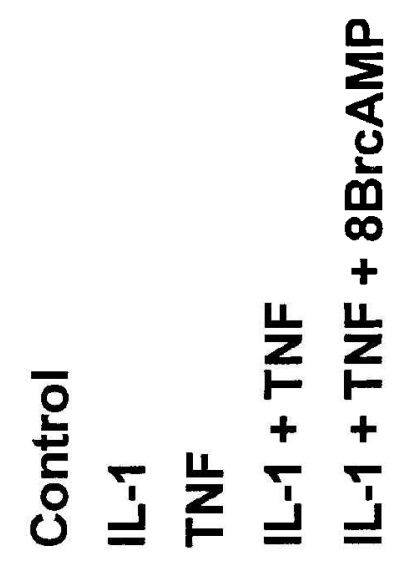

\section{$28 \mathrm{~S}$}

$18 \mathrm{~S}$

GM-CSF

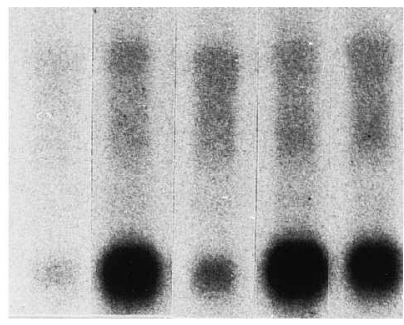

\section{$28 \mathrm{~S}$}
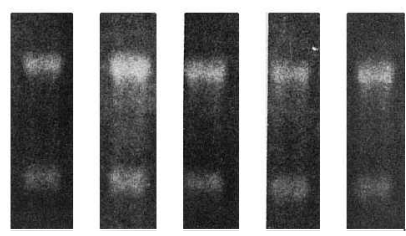

FIG. 1. Induction of GM-CSF mRNA in human bone marrow stromal cells. Confluent secondary stromal cultures were incubated for $6 \mathrm{~h}$ in medium al one or with the addition of IL-1 $(100 \mathrm{U} / \mathrm{ml})$, TNF- $\alpha(500 \mathrm{U} / \mathrm{ml})$, IL-1 plus TNF- $\alpha$ with or without 8BrcAMP $(0.5 \mathrm{mM})$. Total cellular RNA was prepared and subjected to Northern-blot analysis with cDNA probe for human GM-CSF. The 18 and 28S rRNA from ethidium bromide stained gel is shown as loading control. Data are representative for two experiments with stromal cells from different donors. 

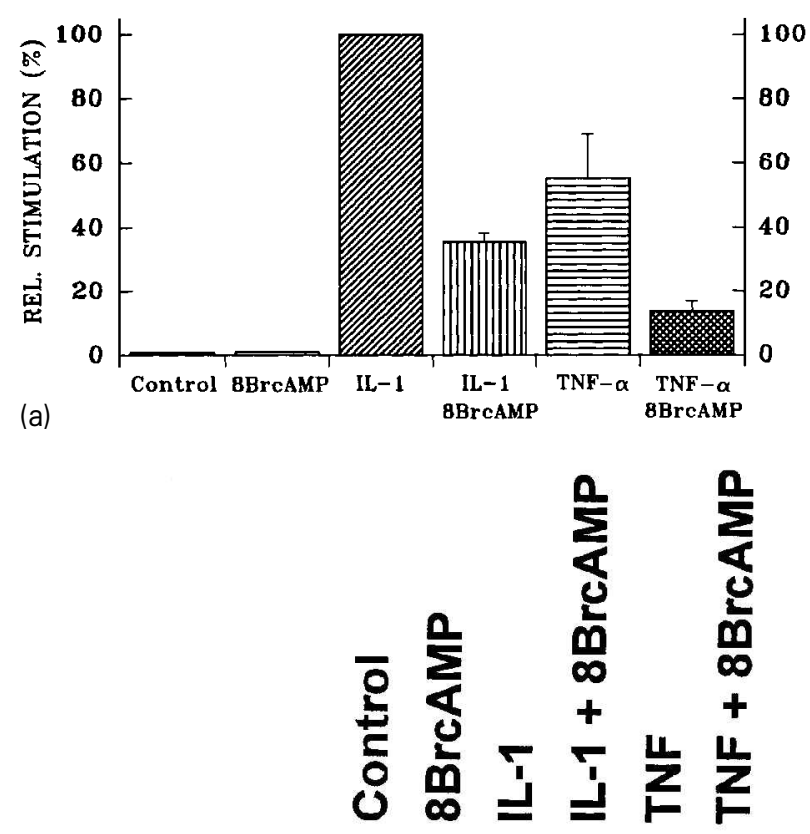

\section{GM-CSF}

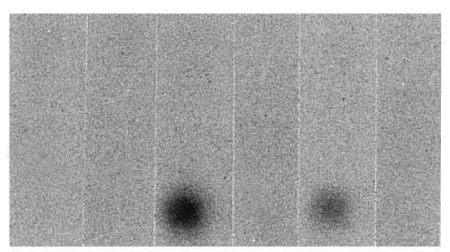

$28 \mathrm{~S}$

$18 \mathrm{~S}$

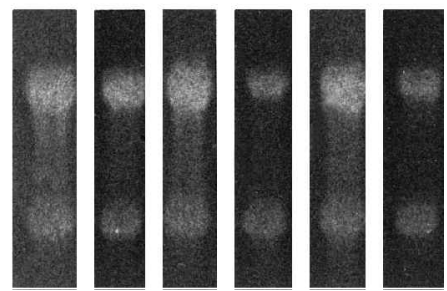

(b)

FIG. 2. Effect of 8BrcAMP on the expression of GM-CSF by human stromal cells. Confluent secondary stromal cultures were incubated in medium alone or with the addition of IL-1 $(100 \mathrm{U} / \mathrm{ml})$, TNF- $\alpha(500 \mathrm{U} / \mathrm{ml}), 8 \operatorname{BrcAMP}(0.5 \mathrm{mM})$ or combinations as indicated. (A) After incubation for $24 \mathrm{~h}, \mathrm{GM}-\mathrm{CSF}$ concentrations in the supernatants were assessed using a specific ELISA. GM-CSF levels are presented as deviation from maximal stimulation. Single experiments were carried out in triplicate, and data from three independent experiments are summarized as mean \pm SEM. (B). After incubation for $6 \mathrm{~h}$, total cellular RNA was prepared and subjected to Northern-blot analysis with cDNA probe for human GM-CSF. The 18 and 28S rRNA from ethidium bromide stained gel is shown as loading control. Data are representative for three experiments with stromal cells from different donors.

IL-1 again being the stronger stimulus. Because the absolute amount of GM-CSF expression varied between experiments, the protein level in culture supernatants from pooled experiments is depicted in Fig. 2A relative to the maximal stimulation.

The addition of the cAMP agonist 8BrcAMP to stromal cell cultures, stimulated by IL-1, TNF- $\alpha$ or the combination of IL-1 and TNF- $\alpha$, resulted in sig- nificantly reduced GM-CSF mRNA expression. Similarly, the GM-CSF protein secretion, induced by IL-1 or TNF- $\alpha$, was inhibited with $8 \operatorname{BrcAMP}(0.5 \mathrm{mM})$ coincubation by $65.5 \pm 2.9 \%$ or $61.6 \pm 6.1 \%$ respectively. These results were obtained by pooling data from three independent experiments (Figs 1 and 2). Dose dependence of the modulatory effect of 8 BrcAMP on GM-CSF secretion was evaluated at concentrations between 0.1 and $1.0 \mathrm{mM}$. Significant inhibition of IL-1 stimulated GMCSF secretion was observed at $8 \mathrm{BrcAMP}$ concentrations of 0.1 to $0.25 \mathrm{mM}$ and the maximal inhibition was seen at concentrations between 0.75 and $1 \mathrm{mM}$ (Fig. 3).

\section{Different cAMP agonists inhibit GM-CSF expression in stimulated human bone marrow stromal cells}

In order to evaluate whether the results obtained by 8 BrcAMP incubation of human bone marrow stromal cells on GM-CSF expression could be generalized to other cAMP agonists we tested a panel of substances. IL-1 stimulated GM-CSF protein secretion into stromal cell supernatants was inhibited by all investigated cAMP agonists including forskolin at $10 \mu \mathrm{M}(81.6 \pm$ 5.8 inhibition), dibutyryl-cAMP at $1 \mathrm{mM}(66.1 \pm 8.1 \%$ inhibition), pertussis toxin at $1 \mu \mathrm{g} / \mathrm{ml}(59.0 \pm 4.6 \%$ inhibition), and $\mathrm{PGE}_{2} 1 \mu \mathrm{g} / \mathrm{ml}$ (36.4 $\pm 14 \%$ inhibition). These data were confirmed by Northern blot analysis at the mRNA level. The coincubation of stromal cell cultures stimulated by IL-1 with forskolin, $\mathrm{PGE}_{2}$, dibutyryl-cAMP, and pertussis toxin led to abolishment of GM-CSF mRNA expression. On the other hand, the cyclooxygenase inhibitor and indirect cAMP antagonist indomethacin had no significant

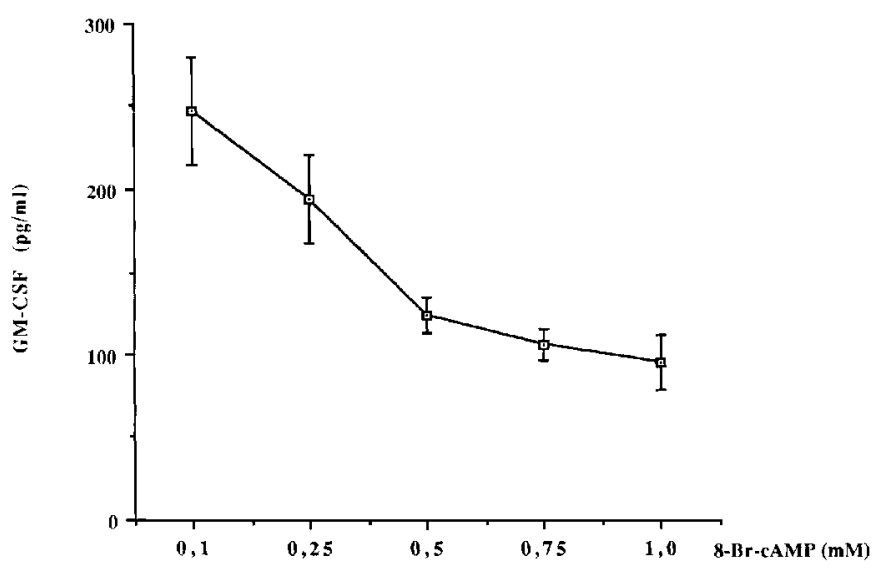

FIG. 3. Dose-dependents of the inhibitory effect of 8BrcAMP on the synthesis of GM-CSF in stromal cells. Confluent secondary stromal cultures were incubated for $24 \mathrm{~h}$ in medium containing $\mathrm{IL}-1(100 \mathrm{U} / \mathrm{ml})$ with increasing concentrations of $8 \mathrm{BrCAMP}$ ranging from 0.1 to $1 \mathrm{mM}$. The GM-CSF concentration in the supernatants was assessed using a specific ELISA. Experiments were carried out in triplicate, and data from three independent experiments are summarized as mean \pm SEM. 

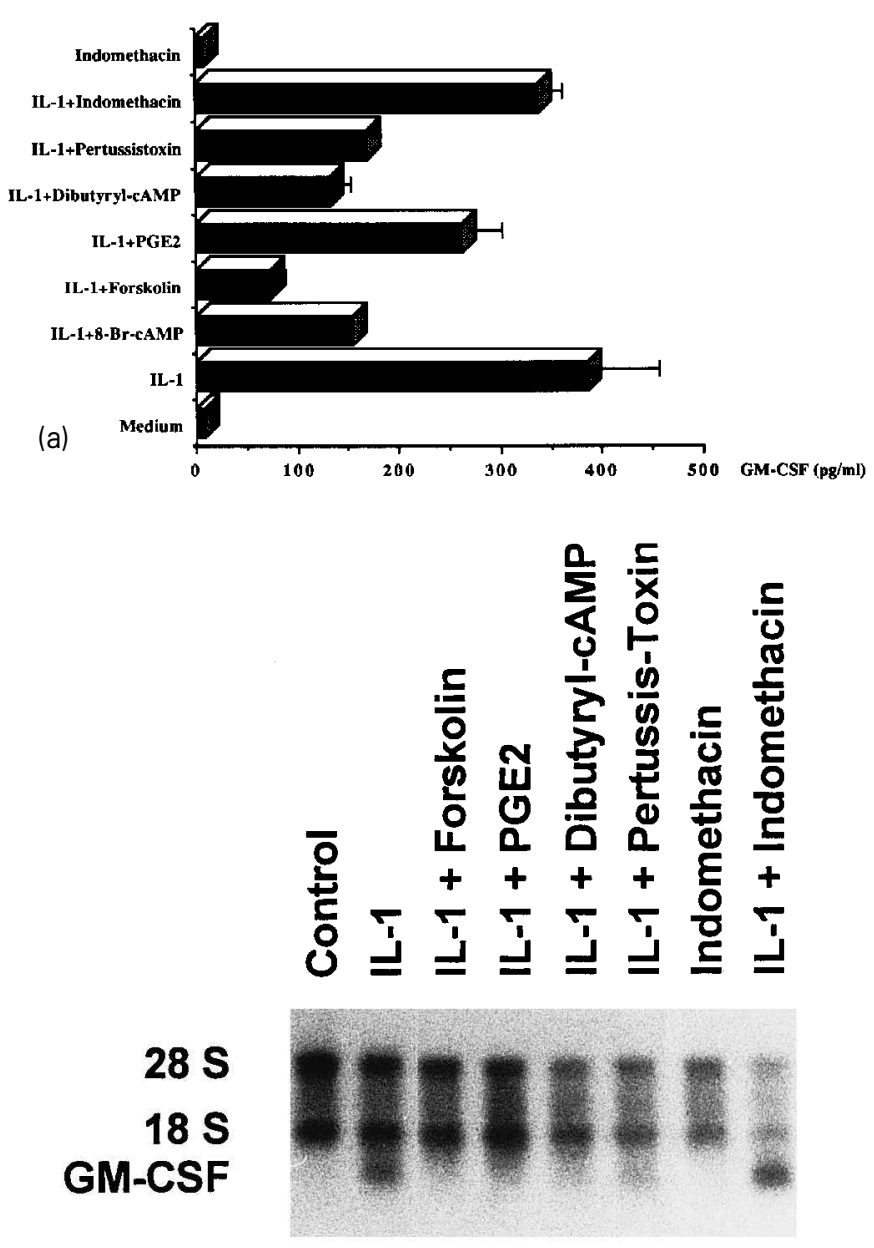

$28 \mathrm{~S}$

$18 \mathrm{~S}$

(b)

FIG. 4. Effect of different cAMP antagonists on the expression of GM-CSF by human stromal cells. Confluent secondary stromal cultures were incubated in medium alone or with the addition of the indicated stimuli. Concentrations used: IL-1 $(100 \mathrm{U} / \mathrm{ml})$, forskolin $(10 \mu \mathrm{M}), \mathrm{PGE}_{2}(1 \mu \mathrm{M})$, dibuturyl-cAMP $(1 \mathrm{mM})$, pertussis toxin $(1 \mu \mathrm{g} / \mathrm{ml})$, indomethacin $(10 \mu \mathrm{M})$. (A) After incubation for $24 \mathrm{~h}, \mathrm{GM}$-CSF concentrations in the supernatants were assessed using a specific ELISA. GM-CSF levels are presented as deviation from maximal stimulation. Single experiments were carried out in triplicate, and data from three independent experiments are summarized as mean \pm SEM. (B) After incubation for $6 \mathrm{~h}$ total cellular RNA was prepared and subjected to Northern-blot analysis with cDNA probe for human GM-CSF. The 18 and 28S rRNA from ethidium bromide stained gel is shown as loading control. Data are representative for two experiments with stromal cells from different donors.

inhibitory influence on GM-CSF protein or mRNA expression (Fig. 4).

\section{Discussion}

The presented data show that GM-CSF is produced in adherent human bone marrow stromal cell cultures after stimulation with inflammatory cytokines IL-1 and TNF- $\alpha$. This effect has previously been reported by several other groups. ${ }^{9-11}$ Some authors also described the endogenous expression of GMCSF in the adherent layer of human Dexter-type cultures without ex ternal cytokine stimulation. GMCSF mRNA could until now unequivocally only be demonstrated by PCR technique in stromal cells cultures. ${ }^{9,10,12}$ Charbord et al. ${ }^{13}$ showed the inhibition of GM-CSF activity in complete Dexter-type cultures by neutralizing monoclonal antibodies that suppressed $70 \%$ of the endogenous CFU-GM. In our culture system, we could not demonstrate significant production of GMCSF in human stromal cell cultures by a sensitive ELISA. This fact could be due to the deprivation of haematopoietic cells. These cells are likely to exert a paracrine stimulatory effect on adherent mesenchymal stromal cells and explain the constitutive expression of GM-CSF in complete Dexter-type cultures.

Both IL-1 and TNF- $\alpha$ were able to induce GM-CSF in bone marrow stromal cell cultures, with IL-1 being the more potent inducer. These results are in accordance with published data. ${ }^{11}$

In a variety of investigated systems, it has been shown that incubation with cAMP agonists causes a differential effect on the production of cytokines. While some cytokines, such as interleukin-6 and leukaemia inhibitory factor, are induced by increased intracellular cAMP concentrations, the expression of other cytokines is inhibited. ${ }^{14-16}$ To the latter group belong macrophage-colony stimulating factor, IL-1, platelet derived grow th factor, and GM-CSF ${ }^{17-19}$ Patil and Borch reported on the inhibitory role of $\mathrm{PGE}_{2}$ on GM-CSF production in human fibroblasts. This effect was mediated by increased intracellular cAMP levels. Our group has described a similar finding of $\mathrm{PGE}_{2}$ and other cAMP agonists inhibiting GM-CSF expression in a murine bone marrow stromal cell line. ${ }^{20,21}$ The present data proves the same inhibitory effect of increased intracellular cAMP concentration in human bone marrow stromal cells at the protein and mRNA level. This inhibition was dose-dependent as shown by increasing suppression of IL-1-induced GM-CSF protein production by the water-soluble cAMP analogue 8 BrcAMP. Maximal inhibition of about $60 \%$ was obtained at a concentration of $0.75 \mathrm{mM}$. The inhibitory action of $8 \mathrm{BrcAMP}$ was demonstrated on GM-CSF expression induced by IL-1, TNF- $\alpha$, or the combination of IL-1 and TNF- $\alpha$. The interference with the stimulatory action of different cytokines indicates that cAMP interacts with components that are either shared among different signalling pathways or act downstream from the convergence point of these pathways. However in earlier experiments on the murine bone marrow stromal cell line $+/+-1$.LDA1 1 we demonstrated that IL-1 and TNF- $\alpha$ incubation had no influence on intracellular cAMP levels. ${ }^{20}$

In addition to the water soluble cAMP analogues 8BrcAMP and dibutyryl-cAMP other cAMP agonists 
like forskolin, $\mathrm{PGE}_{2}$ or pertussis toxin were shown to inhibit GM-CSF ex pression. $\mathrm{PGE}_{2}$ is known to increase the intracellular cAMP synthesis in mesenchymal bone marrow cells. ${ }^{22}$ In contrast to data obtained by Hamilton et al. ${ }^{23}$ in synovial fibroblasts our data did not show an additive effect of the cyclooxygenase inhibitor indomethacin on the IL-1 stimulated GM-CSF induction. This discrepancy may be related to different levels of cyclooxygenase activity in different cellular systems. A regulatory loop has been described by which IL-1 induced GM-CSF expression is downregulated later by IL-1 induced $\mathrm{PGE}_{2} \cdot{ }^{24}$ Prostaglandins are known to exert an inhibitory action on proliferation of haematopoietic progenitor cells. ${ }^{25-27}$ The mechanism of this effect is not completely understood yet. It seems likely that this inhibition, at least in part, is mediated by a decreased expression of haematopoietic grow th factors like GM-CSF by accessory cells.

The mechanism of action by which cAMP decreases GM-CSF expression in stromal cells has been evaluated by our group in a murine bone marrow stromal cell line before. Cyclic-AMP was found to induce the synthesis of a protein which in turn decreased GM-CSF-mRNA stability. ${ }^{21}$ The same mechanism of action has been reported in human lung fibroblasts. ${ }^{24}$ Overall the present data provide evidence for the previously described inhibitory effect of the second messenger cAMP on the GM-CSF expression occurring in human bone marrow stromal cells. This signalling pathway may be involved in the action of different inhibitory hormones like $\mathrm{PGE}_{2}$ on haematopoiesis.

\section{References}

1. Kittler EL, McGrath H, Temeles D, Grittenden RB, Kister VK, Quesenberry PJ. Biologic significance of constitutive and subliminal grow th factor production by bone marrow stroma. Blood 1992; 79 : 3168-3178.

2. Frei K, Piani D, Malipiero UV, Van Meir E, de Tribolet N, Fontana A. Granulocyte-macrophage colony-stimulating factor (GMCSF) production by glioblastoma cells. Despite the presence of inducing signals GM-SF is not expressed in vivo. J Immunol 1992; 148: 3140-3146.

3. Wang Q-R, Wolf NS. Dissecting the hematopoietic microenvironment. VIII. Clonal isolation and identification of cell types in murine CFU-F colonies by limiting dilution. Exp Hema tol 1990; 18: 355-359.

4. Slack JL, Nemunaitis J, Andrews DF III, Singer JW. Regulation of cytokine and grow th factor gene expression in human bone marrow stromal cells transformed with simian virus 40. Blood 1990; 75: 2319-2327.

5. Gimble JM, Pietrangeli A, Dorheim MA, Silver J, Namen A, Takeichi M, Goridis C, Kincade PW. Characterization of murine bone marrow and spleen-derived stromal cells: analysis of leukocyte marker and growth factor mRNA transcript levels. Blood 1989; 74: 303-311.

6. Anderson DM, Lyman SD, Baird A, Wignall JM, Eisenman J, Rauch C, March C, Boswell HS, Gimpel SD, Cosman D, Williams DE. Molecular cloning of mast cell grow th factor, a hematopoietin that is active in both membrane bound and soluble forms. Cell 1990; 63: 235-243.

7. Aman MJ, Rudolf G, Goldschmitt J, Aulitzky WE, Lam C, Huber C, Peschel C. Type I interferons are potent inhibitors of interleukin-8 production in hematopoetic and bone marrow stromal cells. Blood 1993; 82: 2371.

8. Asubel FM, Brent R, Kingston RE. Current Protocols in Molecular Biology. New York: Wiley, 1987.
9. Deschaseaux ML, Herve P, Charbord P. The detection of colonystimulating factors and steel factor in adherent layers of human long-te rm marrow cultures using reverse-transcriptase polymerase chain reaction. Leukemia 1994; 8: 513-519.

10. Aman MJ, Keller U, Derigs G, Mohammadzadeh M, Huber C, Peschel C. Regulation of cytokine expression by interferon alpha in human bone marrow stromal cells: inhibition of hematopoietic growth factors and induction of IL-1 receptor antagonist. Blood 1994; 84: 4142-4150.

11. Caldwell J, Emerson SG. IL-1 alpha and TNF alpha act synergistically to stimulate production of myeloid colony-stimulating factors by cultured human bone marrow stromal cells and cloned stromal cell strains. J Cell Physiol 1994; 159: 221-228.

12. Guba SC, Sartor CI, Gottschalk LR, Jing YH, Mulligan T, Emerson SG. Bone marrow stromal fibroblasts secrete interleukin-6 and granulocytemacrophage colony-stimulating factor in the absence of inflammatory stimulation: de monstration by serum-free bioassay, enzyme-linked immunosorbent assay, and reverse transcriptase polymerase chain reaction. Blood 1992; 80: 1190-1198.

13. Charbord P, Tamayo E, Saeland S, Duvert V, Poulet J, Gown AM, Herve P. Granulocyte-macrophage colony-stimulating factor (GMCSF) in human long-term bone marrow cultures: Endogeneous production in the adherent layer and effect of exogeneous GMCSF on granulomonopoiesis. Blood 1991; 78: 1230-1236.

14. Kasahara T, Yagisawa H, Yamashita K, Yamaguchi Y, Akiyama Y. IL1 induces proliferation and IL6 mRNA expression in a human astrocytoma cell line: positive and negative modulation by chorela toxin and cAMP. Biochem Biophys Res Commun 1990; 167: 1242-1248.

15. Gimble JM, Hudson J, Henthorn J, Hua XX, Burstein SA. Regulation of interleukin 6 expression in murine bone marrow stromal cells. Exp Hematol 1991; 19: 1055-1060.

16. Derigs HG, Boswell HS. LF mRNA expression is transcriptionally regulated in murine bone marrow stromal cells. Leukemia 1993; 7: 630-634.

17. Sherman ML, Weber BL, Datta R, Kufe DW. Transcriptional and posttranscriptional regulation of macrophage-specific colony stimulating factor gene expression by tumor necrosis factor. Involvement of arachidonic acid metabolites. J Clin Invest 1990; 85: 442-447.

18. Abboud SL Regulation of platelet-derived growth factor A and B chain gene expression in bone marrow stromal cells. J Cell Physiol 1995; 164: 434-440.

19. Knudsen PJ, Dinarello CA, Storm TB. Prostaglandins posttranscriptionally inhibit monocyte expression of interleukin 1 activity by increasing intracellular cyclic adenosine monophosphate. J Immunol 1986; 10: 3189-3194.

20. Derigs HG, Burgess GS, Klingberg D, NahreiniTS, Mochizuki DY, Williams $\mathrm{DE}$, Boswell HS. Role for cyclic AMP in the postreceptor control of cytokine-stimulated stromal cell growth factor production. Leukemia 1990; 4: 471-479.

21. Derigs HG, Reifel-Miller A, Kaushansky K, Hromas RA, Boswell HS. GMCSF expression is regulated at transcriptional and posttranscriptional levels in a murine bone marrow stromal cell line. Exp Hema tol 1994; 22: 924-932.

22. Scutt A, Zeschnigk M, Bertram P. PGE2 induces the transition from nonadherent to adherent bone marrow mesenchymal precursor cells via a cAMP/EP2-mediated mechanism. Prostaglandins 1995; 49: 383-395.

23. Hamilton JA, Piccoli DS, Cebon J, Layton JE, Rathanaswani P, McColl SR, Leizer T. Cytokine regulation of colony-stimulating factor (CSF) production in cultured human synovial fibroblasts. II. Similarities and differences in the control of interleukin-1 induction of granulocyte-macrophage CSF and granulocyte-CSF production. Blood 1992; 79 : 1413-1419.

24. Patil RR, Borch RF. Granulocyte-macrophage colony-stimulating factor expression by human fibroblasts is both upregulated and subsequently downregulated by interleukin-1. Blood 1995; 85: 80-86.

25. Pelus LM, Gentile PS. In vivo modulation of myelopoesis by prostaglandin E2. III. Induction of suppressior cells in marrow and spleen capable of mediating inhibition of CFU-GM proliferation. Blood 1988; 71: 1633-1640.

26. Gentile P, Byer D, Pelus LM. In vivo modulation of murine myelopoes is following intravenous administration of prostaglandin E2. Blood 1983; 62: $1100-1107$.

27. Gentile PS, Pelus LM In vivo modulation of myelopoiesis by prostaglandin E2. IV. Prostaglandin E2 induction of myelopoietic inhibitory activity. J Imm unol 1988; 141: 2714-2720.

ACKNOWLEDGEMENTS. This study was supported by a research grant from the 'Deutsche Forschungsgemeinschaft' (De 404/2-1).

Received 12 December 1997; accepted in revised from 25 February 1998 


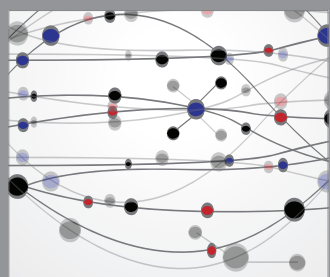

The Scientific World Journal
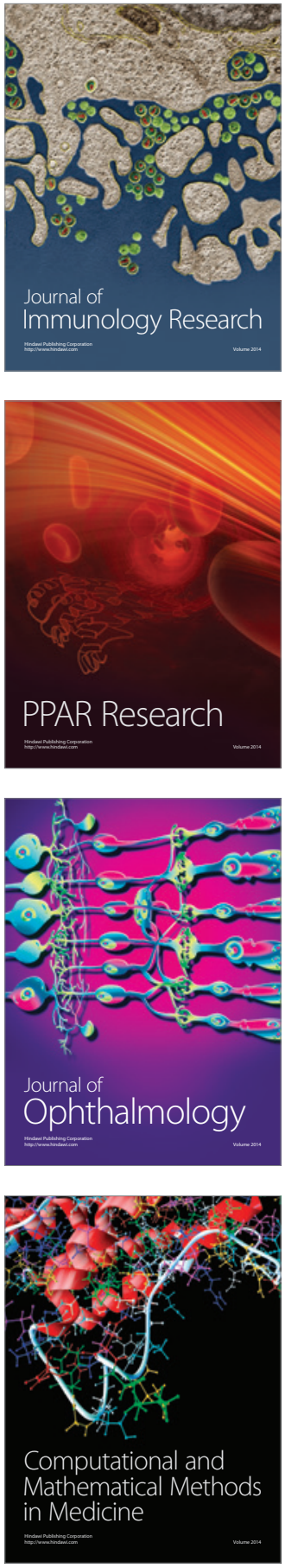

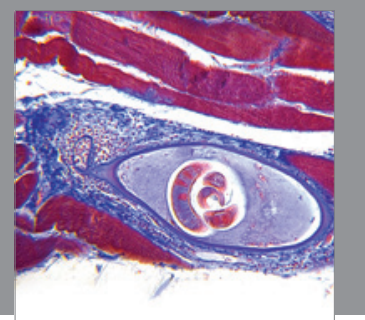

Gastroenterology

Research and Practice
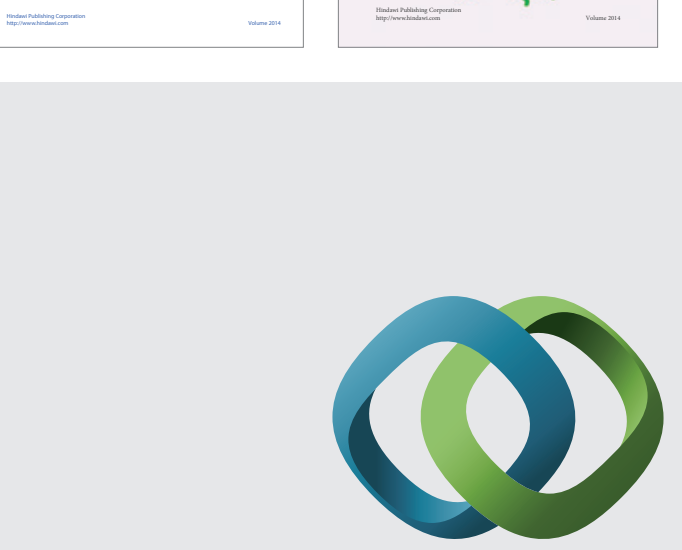

\section{Hindawi}

Submit your manuscripts at

http://www.hindawi.com
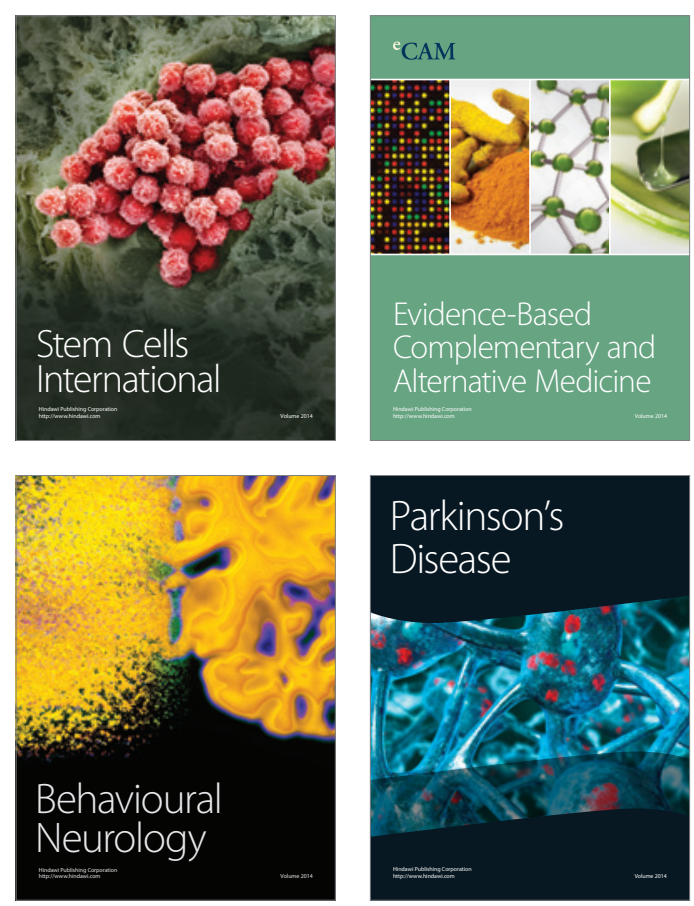

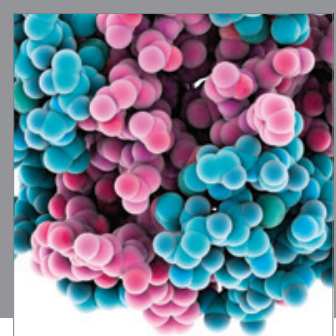

Journal of
Diabetes Research

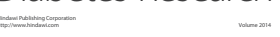

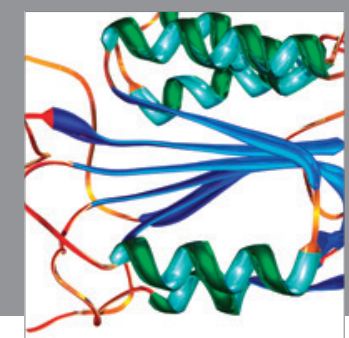

Disease Markers
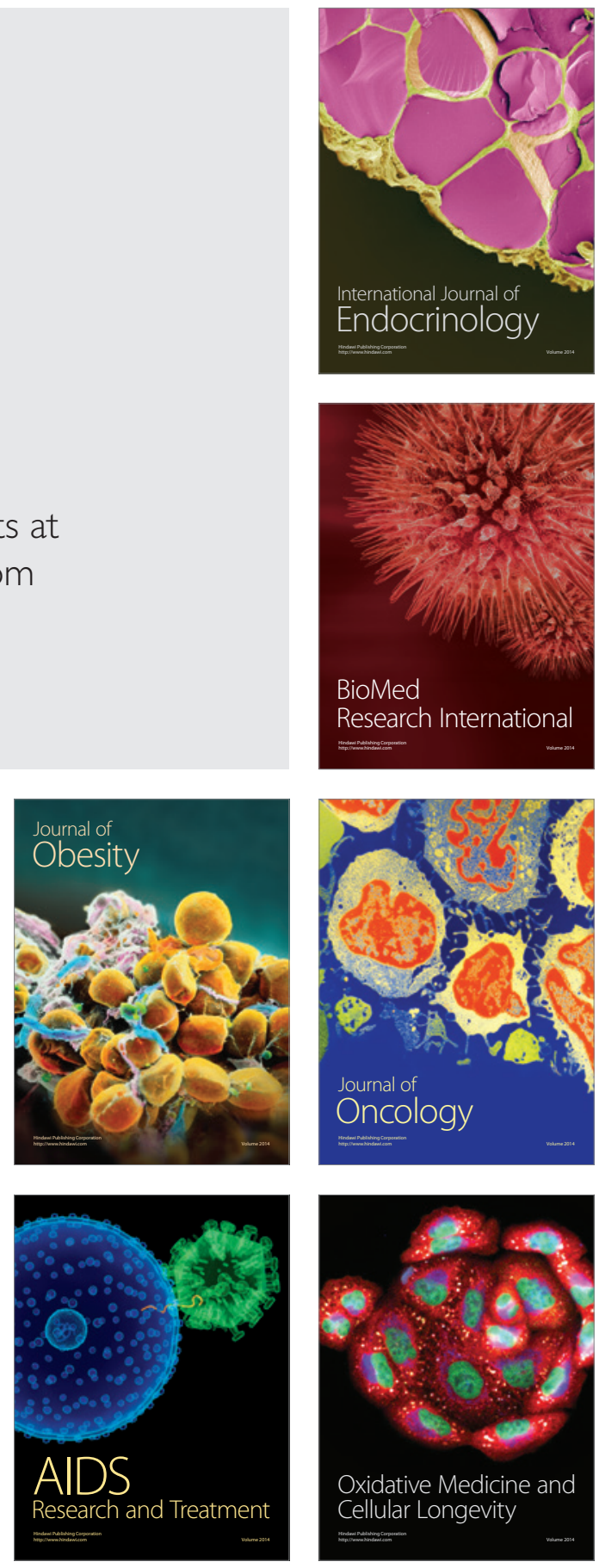